\title{
Students' Social Interaction Ability at Class Viii Of Mts Negeri Gorontalo
}

\author{
Tuti Wantu \\ Department of Guidance and Counseling, Faculty of Education, State University of Gorontalo \\ Corresponding e-mail: tutiwantu67@gmail.com
}

\begin{abstract}
This research aims at investigating students' social interaction ability at class VIII of MTs Negeri Gorontalo. This is a descriptive quantitative research with one variable design namely students' social interaction ability. Samples of this research are 31 students at class VIII of MTs Negeri Gorontalo.

Research findings reveal that (1) first indicator is about doing feedback relation in interaction for $64 \%$ or it is classified as sufficient, (2) the second indicator is about mutual influence in interaction for $75 \%$ or it is classified as sufficient, (3) the third indicator is having obvious purpose and intention in interaction for $80 \%$ or it is classified as sufficient, (4) indicator of social media in interaction for $83 \%$ or it is classified as good. Therefore, it can be accumulated that the students' average social interaction ability is $75.5 \%$.
\end{abstract}

Keywords: Ability, Social Interaction, Students

\section{INTRODUCTION}

Humans are social beings, man that needs a relationship with other human beings. Social interaction among humans is characterized by relationships between individuals and individuals, as well as individuals with groups. Since humans are born, Social interaction has occurred, although in the form of cues, such as crying on the baby. At the next stage, the interaction continues and evolves according to the stages of development that it undergoes.

Woodworth (In Ahmadi, 2007:48) state that human relationships with the environment include: (1) Individuals could be in conflict with the environment, (2) Individuals could use the environment, (3) Individuals could participate with the environment, and (4) Individuals could adapt themselves to the environment.

The general form of social processes is social interaction, while the particular form is social activities. Social interaction in the form of influence relationship that appears in the association of living together. Without social interaction there can be no community life. Social interaction occurs between a person and another person, between a person and a social group and between social groups and other social groups. According to Soekanto (Bungin,
2008:55) "Social interaction is a dynamic social relationship concerning the relationships among individuals, among human groups, as well as between individuals and human groups. "

Based on the observations at MTs Negeri Gorontalo school, the students' social interaction ability in the school is classified low, especially in students at class VIII, there are $10 \%$ of students who have lack ability of good social interaction which is indicated by the symptoms which are students who rarely communicate with classmates and others, be afraid of communicating with teachers or homeroom teacher, rarely interacting with others, not dare to appear in public, not dare to express opinions during discussions, afraid of asking questions, and also there are very closed students who rarely associate with classmates, often solitude, so that social interaction ability is still low.

Social interaction among humans is characterized by relationships between individuals and individuals, as well as individuals with groups. Humans as social beings perform social relationships among themselves in their lives. In social relationships the individual realizes that in social life they will need the help of others. The need for this aid is the beginning of social interaction with others. 
Thus human life in society has two kinds of functions that function as objects and as subjects. Likewise other human beings (milieu), also serve as subjects and objects. That is why then H. Bonner in his book Social Psychology gives the formula that "Social interaction is a relationship between individuals or more, in which the behavior of one individual affects, changes, or improves the behavior of the other individual or vice versa" (in Ahmadi, 2007: 49).

Social interaction is a dynamic social relationship involving the relationship between individuals and human groups (in Syarbaini and Rusdiyanta, 2009: 26). Without social interaction there can be no social life. Social interaction occurs between a person and another person, between a person and a social group and between social groups and other social groups.

According to Walgito (2003: 57), "Social interaction is the relationship between the individual one with the other individual, the individual one can affect another individual or vice versa, so there is a mutual relationship". Homans (in Ali, 2004: 87), defines "Interaction as an event when an activity or sentiment is performed by a person against another individual is reward or punishment by using an activity or sentiment by another individual who is being her/his partner. Therefore, the concept proposed by Homans contains the notion that an action performed by a person in the interaction is a stimulus for the actions of other individuals who become her/his partner.

According to Shaw (in Ali, 2004: 87), states that, "Social interaction is an interpersonal exchange that each man shows his or her behavior with each other in their presence, and each behavior affects each other." The same thing was also put forward by Thibaut and Kelley (in Ali, 2004: 87), that "Social interactions as events affect each other when two or more people are present together, they create a result of each other or communicate with each other." As for Sargent (in Santosa, 2004: 11) states that "Social interaction essentially sees social behavior always within the framework of groups such as structure and function in groups."

Based on several experts' opinion above, the author conclude that social interaction is a mutual relationship among human beings that affect each other both in the relationship among individuals, among groups and between individuals and groups.

Social interaction can be defined as dynamic social relationships. In social interaction there are several characters contained in, among them is according to Santosa (2004: 11) who said that "The characteristics of social interaction is the existence of relationship; Individuals existence; there is a goal; and the existence of relationship with social structure and function ". In detail the description is as follows: (1) The existence of the relationship, that is in every interaction must occur because of the relationship between individuals and individuals as well as between individuals and groups, (2) There are individuals, i.e. every social interaction demands the appearance of individuals who carry out relationships, (3) There is a goal, that every social interaction has a specific purpose such as affecting other individuals, (4) The existence of relationship with structure and function of group, that is social interaction of individual in their life not separated from group. In addition, each individual has a function within her/his group which is carried out through a pattern of a particular social system.

Based on the experts opinion above it can be concluded that the characteristics of good social interaction is the occurrence of communication links among individuals who have a purpose and certain goals such as affecting each other, mutual need, mutual respect and admiration, there is no gang or distance group limiting individuals to other individuals, and helping each other to achieve common goals and in the structure of group functions each individual has functions within the group.

According to Syarbaini and Rusdiyanta (2009: 26), the social process that we discuss only the real, namely social interaction in the form of influence relationship that appears in the association of living together. Without social interaction there can be no community life. Social interaction occurs between a person and another person, between a person and a social group and between social groups and other social groups.

Theoretically there are at least two conditions of social interaction viz.: there is social contact and communication.

1. There is social contact

Social contact is an attempt to approach physical and spiritual meetings. Social contacts can be primary (face to face) and can be secondary (communicating through communication media, intermediate persons or media objects, newspapers, $\mathrm{TV}$, radio, etc.). Social contact could also be positive or negative. Positive social contact leads to a collaboration, whereas negative contact leads to opposition or does not even result in social interaction. 


\section{There is communication}

Communication is an attempt to convey information to other human beings. Without communication there is no possible social interaction. In communication often appear different kinds of interpretation the meaning of other people's behavior due to differences in social context. Communication using simple cues is the most basic and important form of communication. Characteristics of human communication not only using the form of physical signals, but also communicate using words that are sound symbols that contain a common meaning and are standard.

The form of social interaction could be Cooperation, Accommodation, Competition, and Conflict. Conflict leads to the settlement, but in the process can be temporary conditioned, called accommodation" Syahrial Syarbaini and Rusdiyanta (2009:28). Another opinion expressed by Gillin and Gillin (Syahrial Syarbaini and Rusdiyanta, 2009: 28), there are two kinds of social processes that arise as a result of social interaction, namely:

1. The associative process is a social process that indicates a movement of approach or unification. Specific forms of social processes that are associative are cooperation, accommodation, assimilation and acculturation.

2. The dissociative process is a social process that indicates in motion toward division. Specific forms of dissociative processes are compositions, conflicts and controversies.

The elaboration of each form of social interaction is as follows:

1. Associative social process

a. Cooperation

The form and pattern of cooperation can be found in all social groups. Cooperation habits start from childhood in the form of games to villages in all forms of effort to achieve common goals. Cooperation arises because of the orientation of people to the group, then there must be conditions of harmonious division of labor and clear benefits. Cooperation will grow stronger if there is an outside threat or something that offends the value of loyalty, customs of the group. There are three forms of cooperation, namely: (1) Bargaining, that is the implementation of agreements on exchanges and services among two organizations; (2) Cooperation, that is the process of acceptance of new elements in the leadership of an organization to avoid shocks the stability of the organization (mutual support); (3) Coalition, which is a combination of two organizations that have the same goal so that it is cooperative. If the cooperation is based on profit sharing, it is called a joint-venture.

b. Accommodation

Accommodation is a way of resolving opposition without destroying the opposing party, so that the opponent loses his personality. The purpose of accommodation is to reduce human opposition due to differences of understanding, to prevent the explosion of a conflict, an attempt to enable cooperation between social groups and businesses to merge among separate social groups. The forms of accommodation as a process are: (1) Coercion, is accommodation carried out by coercion, such as slavery in society; (2) Compromise, a party is willing to feel and understand the other side's situation and vice versa, for example some political parties are aware that they have the same power in an election; (3) Arbritration, by appointing a third party to be elected by the two higher parties / organizations; (4) Mediation, involving third parties in solving problems peacefully with their role as mediator; (5) Conciliation, An attempt to bring together the wishes of the disputing parties to the achievement of a common goal, for example some elements of the labor problem resolution committee; (6) Toleration, a form of accommodation without the consent of formation of its form, constituted by the character of a human being who does not wish to arise conflict; (7) Stalemate, because the parties are well-balanced so that it stops at a certain point in opposition; (8) Adjudication, court settlement in court.

c. Assimilation and Acculturation

Assimilation is an advanced process of accommodation. In the process of assimilation occurs the process of fusion of culture, so that the parties of various groups who are assimilated will feel the existence of a single culture suggested jointly. The process of assimilation is characterized by efforts to reduce the differences between individuals or groups of people and also encompass efforts to enhance unity of actions, attitudes and mental processes with regard to common interests and goals.

If the assimilation between two different social groups of culture takes place in such a way that the mutual acceptance of other cultural elements becomes a new custom, this is called acculturation. So in acculturation, other cultural elements enter or be accepted as if they belong to themselves or their own culture.

2. Dissociative Social Process 


\section{a. Competition}

Competition is a social process, in which a person or social group competes for the value or gain of the sphere of life through ways of attracting the public. Competition could be private and could be a group or organization. Forms of competition could be: (1) Economic competition, that is the effort to compete for goods and services in terms of quality, quantity, price and service; (2) Cultural competition, which is the effort to introduce cultural values to be accepted and adopted; (3) Social status competition, that is, the effort to attain and compete for a position and a respected role, whether by an individual or by a social group; (4) Race competition, the typical cultural competition represented by the characteristics of race as a symbol of cultural differences.

b. Conflict

Conflict is a social process whereby a person or social group seeks to fulfill its purpose by challenging its opponent with threat or violence. Conflict occurs because the differences are sharpened by emotion / feeling, let alone supported by a third party. The reasons are: (1) Cultural differences that lie behind the attitude or establishment of groups that cause conflict among groups; (2) Differences of opinion or attitude uncontrollable by reason; (3) Clash of interests, such as economic, politic, and so on; (4) Social change is accompanied by changes in attitudes about certain values as a result of change or organized.

\section{d. Contravention}

Contravention comes from the Latin word, contra and venire, which means to block or challenge. In this word contains the meaning of effort to prevent others from reaching the goal. The main thing in this social process is to thwart the accomplishment of the other's goals. The reason is there is a sense of displeasure with the success of other parties that are considered harmful, although not intended to destroy the other party. Contravention can be done in the following ways: (1) Rough and smooth. Rough manner is characterized by impolite, in the form of distraction, derision, defamation, provocation, intimidation. The subtle way can be done by using language and polite behavior, however it contains a sharp meaning; (2) Open and hidden. The open way if done directly by which side and who conducts the social process, and what content. Hidden way is hard to know; (3) Official and unofficial. The official means are the opposition that is accepted and enforced by law or by provisions institutionalized by the State's powers or religious powers. While the unofficial way is a contradiction that is not done by law and is not institutionalized.

Social interaction does not just appear. "Social interaction is the relationship between the individual one and the other individual, the individual one can affect another individual or vice versa, so there is a mutual relationship" (Walgito, 2003: 57). The occurrence of social interaction in individuals can be influenced by several factors, namely"imitation factor, suggestion factor, identification factor, and sympathy factor" (Ahmadi, 2007: 25). Meanwhile, according to Gerungan (2010: 62), the continuity of social interaction in its simple form, it turns out to be a complex process, however can be distinguished some of the underlying factors, either single or join, such imitation factor, suggestion factor, identification factor, sympathy factor.

The researcher conclude from both opinions that the process of social interaction is influenced by several factors, viz. imitation factor, suggestion factor, identification factor, and sympathy factor. Explanation of the four factors are as follows:

1. Imitation Factor

Gabriel Tarde in (Ahmadi, 2007: 52) assumes that all social life is actually based on imitation factors. The role of imitation factor in social interaction as described above also has negative aspects, i.e.:

a. Perhaps the imitation is wrong, so that affect in a collective error that includes a large number of people.

b. Sometimes people who imitate something without criticism, so that it can hamper the development of critical thinking habits. According to Gerungan (2010: 64) explains that "imitation is not a basic foundation of all social interaction, however it is an aspect of the social interaction process, which explains why and how uniformity can occur in view and behavior among the people."

2. Suggestion Factor

According to Ahmadi (2007: 53) "suggestion is a psychic influence, either coming from himself or others, which is generally accepted without any criticism." While Gerungan (2010: 65) defines "suggestion as a process in which an individual accepts a way of seeing or guiding the behavior of others without criticism first". From some opinions it can be concluded that the suggestion is the psychic influence received by individuals without any criticism. 


\section{Identification Factors}

According to Gerungan (2010: 72) who state that "the identification of people to others who considered ideal in a way, to get the system of norms, attitudes, and values that he considered ideal, and still lack from himself. While Ahmadi (2007: 57) argued that "Identification in psychology means the urge to be identical (same) with others, both outwardly and inwardly". The initial identification process takes place in an unconscious (itself) and then irrational, i.e. based on feelings or self-tendencies that are not calculated rationally, and identification is useful to complement the system of norms, ideals, and guidelines the behavior of the person who identifies it. From some of these opinions it can be concluded that the identification is an encouragement made by a person to be identical with others who considered ideal.

\section{Sympathy Factor}

Sympathy is the attraction of one person to another. Sympathy arises not on the basis of logical rational, but rather based on an assessment of feelings as well as in the process of identification. The relationship among the individuals who interact is a mutual relationship of mutual influence.

Social interaction in its simple form, it turns out to be a complex process. There are several underlying factors, explicitly imitation factor, suggestion factor, identification factor, and sympathy factor.

From the above explanation can be concluded that the factors of social interaction is by way of imitation, view and behavior of a person embodies attitudes, ideas, and customs in the community groups and can expand social relationships with others In addition to the imitation factor, there is another factor that is suggestion. Suggestion can be formulated as a process in which an individual accepts a way of seeing or guiding the behavior of others without criticism first. While identification is the urge to become synonymous with others, both outwardly and inwardly. Next sympathy is the feeling of attraction one person to another.

\section{RESEARCH METHOD}

The design of this research is descriptive quantitative research with one variable design namely students' social interaction ability. The sample in this research is students at class VIII of MTs Negeri Gorontalo with total number of 31 students. Technique of collecting data by using likert scale questionnaire. Data analysis technique used in this research is descriptive using statistical calculation percentage (\%) with the formula $(\mathrm{P}=\mathrm{F}$ / $\mathrm{N} \times 100 \%$ ).

\section{RESULTS AND DISCUSSION}

As explained in the previous chapter, the data in this study is distributed using a questionnaire of social interaction consisting of 4 indicators, which is: (1) Doing feedback relation in interaction; (2) Mutual influence in interaction; (3) Having obvious purpose and intention in interaction; (4) Using social media in interaction. The data of research results are described as follows:

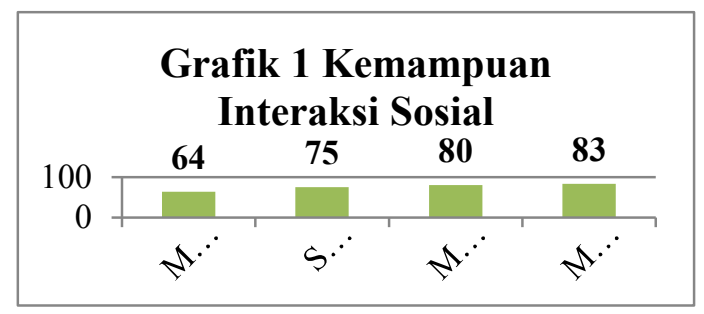

Figure 1 indicates that the indicator of doing feedback relation in interaction at a percentage of $64 \%$ (Sufficient), mutual influence in interaction is at $75 \%$ percentage (Sufficient), having obvious purpose and intention in interaction is at $80 \%$ percentage (Sufficient), using social media in interaction is at $83 \%$ percentage (Good). Based on the data obtained social interaction ability earn $75.5 \%$ percentage.

\section{DISCUSSION}

Based on data obtained from the results of data analysis, which describes about the Study of Students' Social Interaction Ability at Class VIII of Mts Negeri Gorontalo showed that social interaction ability obtained $75.5 \%$ percentage this can be interpreted that students have lack social interaction with others because there is no feedback relation in interaction. To follow up the problem, it is hoped that BK teachers can give understanding to students that having a face-to-face social interaction relationship is more important than engaging in social interaction through the use of social media. This percentage is derived from the accumulation of each indicator. Where the ability of social interaction is only consists of four indicators:

1. Doing feedback relation in interaction 
Based on the results of research concerning doing feedback relation in interaction Indicator, obtained the observation result of $64 \%$, it means that social interaction ability that existed in Class VIII students of MTs Negeri Gorontalo is still in sufficient category. What is meant by doing feedback relation in interaction is in every interaction must occur because of the relationship between individuals and individuals and between individuals and groups (Santosa, 2004: 11).

2. Mutual influence in interaction

Based on the results of research concerning mutual influence in interaction indicator, obtained $75 \%$, it means that social interaction ability that existed in Class VIII students of MTs Negeri Gorontalo is still in good category. Which has the ability of social interaction can be seen from how students influence others in interacting in order to occur a good communication. What is meant by mutual influence in interaction is in which the behavior of one individual affects, changes, or improves the behavior of the other individual or vice versa" $\mathrm{H}$. Bonner (in Ahmadi, 2007: 49).

3. Having obvious purpose and intention in interaction

Based on the results of research concerning having obvious purpose and intention in interaction indicator, obtained $80 \%$, it means that social interaction ability that existed in Class VIII students of MTs Negeri Gorontalo is still in good category. Where students should have obvious purpose and intention in interaction in order to avoid misunderstanding in communication. The meaning of having a clear intent and purpose in interacting is every social interaction has a specific purpose such as affecting other individuals (Santosa, 2004: 11).

4. Using social media in interaction

Based on the results of research concerning using social media in interaction indicator, obtained $83 \%$ it means that social interaction ability that existed in Class VIII students of MTs Negeri Gorontalo is still in good category. Where in doing social interaction is not only done directly, however through social media can also be interacted. The meaning of using social media in interaction is implemented through a pattern of a particular social system (Team Sociology, 2002: 23).

\section{CONCLUSION}

Based on the research results and discussion that have been explained on the Study of Students' Social Interaction Ability at Class VIII of Mts Negeri Gorontalo, it can be described that, based on the results of the overall recapitulation of each indicator of social interaction ability of students consisting of four indicators, that is the first indicator doing feedback relation in interaction earn a percentage of $64 \%$, the second indicator mutual influence in interaction obtains the percentage of $75 \%$, the third indicator having obvious purpose and intention in interaction, obtaining a percentage of $80 \%$, and indicator using media social interaction, earning a percentage of $83 \%$. Therefore it can be accumulated that the result of the average percentage result of social interaction ability is $75.5 \%$.

\section{REFERENCES}

[1] Ahmadi, Abu. (2007). Psikologi Sosial. Rineka Cipta. Semarang.

[2] Ali, Mohammad dan Mohammad Asrori.

(2004). Psikologi Remaja (Perkembangan Peserta Didik). Bumi Aksara. Jakarta.

[3] Ariokonto \& Suharsimi. (2010). Prosedur Penelitian Suatu Penelitian Praktis Asdi Mahasatya. Jakarta.

[4] Azwar, Saifuddin. (2012). Reliabilitas dan Validitas. Pustaka Pelajar. Yogyakarta.

[5] Bungin, Burhan. (2008). Sosiologi Komunikasi (Teori, Paradigma, dan Diskursus

Teknologi Komunikasi di Masyarakat). Prenada Media Group. Jakarta.

[6] Gerungan, W.A. (2010). Psikologi Sosial. Refika Aditama. Bandung.

[7] Santosa, Slamet. (2004). Dinamika Kelompok. Bumi Aksara. Jakarta.

[8] Sugiyono. (2013). Metode Penelitian Kuantitatif Kualitatif dan $R \& D$. Alfabeta. Bandung.

[9] Sujana. (2002). Metode Statistika. Tarsito. Bandung.

[10] Syarbaini, Syahrial dan Rusdiyanta. (2009). Dasar-dasar Sosiologi. Graha Ilmu. Jakarta.

[11] Walgito, Bimo. (2003). Psikologi Sosial (Suatu Pengantar). Andi Offset. Yogyakarta. 